\title{
Process Optimization of $\beta$-glucosidase Production by a Mutant Strain, Aspergillus niger C112
}

\author{
Peng Zhan, ${ }^{\text {a,b,c }}$ Jingjing Sun, ${ }^{\text {a,b,d }}$ Fang Wang, ${ }^{\text {a,b }}$ Lin Zhang, ${ }^{\text {a,b,c }}$ and Jienan Chen ${ }^{\text {a,b,c,e,* }}$ \\ Enzymatic saccharification is a key step in the green conversion of \\ lignocellulose to biofuels and other products. A key deficiency in common \\ biocatalytic systems, such as Trichoderma reesei, is the insufficient \\ presence of $\beta$-glucosidase (BGL). This study intended to develop an \\ efficient process of BGL production as an enhancement to the $T$. reesei \\ system. The authors investigated the process optimization of BGL by the \\ mutant strain Aspergillus niger $\mathrm{C} 112$, which was previously developed in \\ the authors' laboratory. The culture medium and process (carbon, \\ nitrogen, temperature, and $\mathrm{pH}$ ) were optimized for cost-effective BGL \\ production, which led to a maximum BGL activity of $8.91 \pm 0.35 \mathrm{U} / \mathrm{mL}$. In \\ addition, the dynamics of the physio-chemical parameters (zeta potential \\ and dissolved organic matter) of the process were studied and showed \\ good correlations to the yield of BGL. Furthermore, a three-dimensional \\ excitation-emission matrix fluorescence spectroscopy was successfully \\ applied for analyzing the component, origin, and dynamics of dissolved \\ organic matter, which contributed to a further understanding and \\ optimization of BGL production.
}

Keywords: $\beta$-glucosidase; Aspergillus niger; Process optimization; Fermentation; Biorefinery;

Excitation-emission matrix fluorescence spectroscopy

Contact information: a: Ministry of Forestry Bioethanol Research Center, Changsha 410004, China; b: Hunan Engineering Research Center for Woody Biomass Conversion, Changsha 410004, China; c: School of Materials Science and Engineering, Central South University of Forestry and Technology, Changsha 410004, China; $d$ : Institute of Division of Life Science, Hong Kong University of Science and Technology, Hong Kong 999077, China; e: Transpoints Inc., P.O. Box 141742, Gainesville, FL 32614, USA; *Corresponding author: chenjnx@163.com

\section{INTRODUCTION}

The enzymatic saccharification of sugar-based macromolecules (cellulose and hemicellulose) of lignocellulose biomass is crucial for the production of biofuels (e.g. ethanol and butanol) and other products (e.g. lactic acid and polyhydroxyalkanoates) (Hasunuma et al. 2013; Maity 2015). Under the synergistic actions of at least three cellulase families (endoglucanase, exocellobiohydrolase, $\beta$-glucosidase, etc.), cellulose is hydrolyzed and saccharified smoothly and orderly into glucose, and then converted into targeted products (Fujita et al. 2004; Jeoh et al. 2017). Currently, industrially and commercially used cellulase preparations have been mostly produced by the fungi Trichoderma spp. (such as Trichoderma reesei), which hold sufficient and robust cellulase such as endoglucanase and exocellobiohydrolase (Barati and Sadegh Amiri 2015). Nevertheless, because of the insufficient presence of $\beta$-glucosidase (BGL) in T. reesei, cellulase preparations improvement should be carried out for cost-effective saccharification (Escamilla-Alvarado et al. 2016). The supplementation and enhancement of BGL produced by other microbes in cellulase preparations is a promising method (Vijaya Rani et al. 2014). 
Many natural microbial sources (Aspergillus, Penicillium, Trichoderma, Saccharomyces, and Pseudomonas, etc.) have been exploited for BGL production, wherein Aspergillus niger is one of the most robust and promising candidates (Narasimha et al. 2016). Currently, much effort has been focused on strain improvement, culture medium, process optimization, etc., to enhance the efficient production of BGL. For example, chemical reagents such as ethyl methanesulfonate, acridine orange, and N-methyl N'-nitroN-nitrosoguanidine, (Pal and Das 2005; Lotfy et al. 2007; Wang et al. 2016), ultraviolet irradiation (Mahalakshmi et al. 2009), gamma radiation (Ottenheim et al. 2015), genome shuffling (Li et al. 2014), protoplast fusion (Khattab and Bazaraa 2005), and regulation target encoding genes (Stricker et al. 2008) were used for A. niger improvement. The feed stock (e.g. corn stover, wheat straw, sugar cane bagasse, wheat bran, and glycerol) (Delabona et al. 2013; Abdella et al. 2014), promoters, inducers (e.g. easily metabolizable sugars, monoterpene glycoside, xylose, maltose, and trace elements) (Shoseyov et al. 1988; $\mathrm{Lu}$ et al. 2010), and nutrient complementation (e.g. organic-inorganic nitrogen complementation) (Wang et al. 2012) were applied for culture medium optimization. The fermentation strategies (e.g. submerged and solid-state fermentation) and process parameters (e.g. inoculum volume, stirring rate, temperature, oxygen, $\mathrm{pH}$, and time) (Park et al. 2002) were involved in the process optimization. However, when aiming at costeffective BGL production and industrialization, a greater emphasis should be focused on the screening of the robust biocatalyst (fermentation microbe), low-cost culture medium (mainly influenced by substrates and nutrients), process optimization, etc. Moreover, the process dynamics should be characterized for cost-effective BGL production.

In this experiment, efforts were made to optimize the medium and process parameters using Response Surface Methodology (RSM) for cost-effective BGL production with a mutant strain $A$. niger $\mathrm{C} 112$. The process physio-chemical properties, such as zeta potential and dissolved organic matter (DOM) in the fermentation broth, were studied and shown to have strong correlations to the BGL yield. Further, the dynamics of DOMs were characterized by a three-dimensional excitation-emission matrix (EEM) fluorescence spectroscopy.

\section{EXPERIMENTAL}

\section{Materials}

The authors' own lab BGL production strains were treated by ultraviolet irradiation for strain optimization. The most vigorous one (holding the biggest BGL production capability) A. niger $\mathrm{C} 112$ was stored in the China Center for Type Culture Collection (CCTCC) (Wuhan, China), holding the strain culture preservation number M2012129 (Shi 2011). One copy of the stored A. niger C112 was used in this paper.

\section{Methods}

\section{Media and culture}

The glycerol-preserved $A$. niger $\mathrm{C} 112$ stored in a $-80{ }^{\circ} \mathrm{C}$ refrigerator was first activated on a potato dextrose agar (PDA) medium $(300 \mathrm{~g} / \mathrm{L}$ potato, $20 \mathrm{~g} / \mathrm{L}$ glucose, and $20 \mathrm{~g} / \mathrm{L}$ agar) for 6 days at $28^{\circ} \mathrm{C}$. Two loops of spores on the PDA medium were inoculated into 250 -mL flasks holding $50 \mathrm{~mL}$ of seed medium ( $300 \mathrm{~g} / \mathrm{L}$ potato and $20 \mathrm{~g} / \mathrm{L}$ glucose) and activated for $48 \mathrm{~h}$ in preparation for inoculation. The well-grown spores (mycelial pellet-shaped ribbon) were inoculated into $250-\mathrm{mL}$ flasks with $50 \mathrm{~mL}$ of fermentation 
medium (Sinopharm Chemical Reagent Co., Ltd., Shanghai, China) that contained $6 \mathrm{~g} / \mathrm{L}$ potassium dihydrogen phosphate $\left(\mathrm{KH}_{2} \mathrm{PO}_{4}\right), 0.9 \mathrm{~g} / \mathrm{L}$ anhydrous calcium chloride $\left(\mathrm{CaCl}_{2}\right)$, $0.9 \mathrm{~g} / \mathrm{L}$ magnesium sulfate $\left(\mathrm{MgSO}_{4}\right), 1 \mathrm{~mL} / \mathrm{L}$ Tween-80, $1 \mathrm{~mL} / \mathrm{L}$ Mandels trace elements $\left(1.4 \mathrm{~g} / \mathrm{L}\right.$ zinc sulfate $\left(\mathrm{ZnSO}_{4}\right), 1.6 \mathrm{~g} / \mathrm{L}$ manganese sulfate $\left(\mathrm{MnSO}_{4}\right), 5 \mathrm{~g} / \mathrm{L}$ ferrous sulfate $\left(\mathrm{FeSO}_{4}\right), 3.7 \mathrm{~g} / \mathrm{L}$ cobalt chloride $\left.\left(\mathrm{CoCl}_{2}\right)\right)$, and $100 \mathrm{~mL} / \mathrm{L}$ citrate buffer, at a $\mathrm{pH}$ of 4.8 . The doses of carbon source and nitrogen source were $30 \mathrm{~g} / \mathrm{L}$ and $7 \mathrm{~g} / \mathrm{L}$, respectively. The culture $\mathrm{pH}$ was not adjusted.

\section{Medium optimization}

Previous studies from our lab (none reported) has indicated that the corn cob, straw powder, wheat bran, bagasse, rice bran, industrial cellulose, corn stalk, and starch (Changsha Minghui Biotech Co., Ltd., Changsha, China) were tested for the effect of carbon source on BGL production. The strategies of inorganic-inorganic nitrogen and organic-inorganic nitrogen complementation were performed for nitrogen source improvement using yeast extract powder, peptone, $\left(\mathrm{NH}_{4}\right)_{2} \mathrm{SO}_{4}$, corn syrup, and $\mathrm{NaNO}_{3}$. In addition, the RSM test of four factors at three different levels using Box-Behnken design was applied by the software Design-Expert 8.0.6 (Stat-Ease, Inc., Minneapolis, USA) for optimization of carbon, nitrogen, temperature, and $\mathrm{pH}$, with three replicates. The data analysis and graphs were conducted by SigmaPlot 13.0 (Systat Software Inc., San Jose, CA, USA).

\section{Process dynamic characterization}

The zeta potential and DOM particle size were both measured using a Malvern Mastersizer 2000 (Malvern Instruments Ltd., Malvern, UK) according to previous literature (Elanthikkal et al. 2010).

The information involved in the component, origin, and dynamics of DOMs was obtained by a Hitachi Spectrophotometer F-4600 (Hitachi Ltd., Tokyo, Japan), according to previous literature (He et al. 2014). The scanning emission (Em) and excitation (Ex) wavelength were $200 \mathrm{~nm}$ to $700 \mathrm{~nm}$ and $350 \mathrm{~nm}$ to $800 \mathrm{~nm}$, respectively, coupled by a scanning speed of $2400 \mathrm{~nm} / \mathrm{min}$. The Rayleigh light scattering was eliminated by a $290 \mathrm{~nm}$ emission cut-off filter. Deionized water was used as a control. The EEM values were analyzed by fluorescence regional integration (FRI) (Chen et al. 2003). The ratio of fluorescence intensity of Em $450 \mathrm{~nm}$ to Em $500 \mathrm{~nm}$ at Ex $370 \mathrm{~nm}\left(f_{450 / 500}\right)$ was measured to determine the origin of humic acid-like matter (McKnight et al. 2001).

\section{Analytical methods}

The sample was pretreated by an Eppendorf 5804 R (Eppendorf, Hamburg, Germany) centrifuge with a $8000 \mathrm{round} / \mathrm{min}(6829(\times \mathrm{g}))$ centrifugation. The supernatant was then filtered with a $0.45 \mu \mathrm{m}$ filter membrane. The filtrate was prepared for analysis.

The BGL activity was measured by the $p$-nitrophenyl- $\beta$-D-galactopyranoside ( $p$ NPG ) method (Abdella et al. 2014). One unit of BGL activity was defined as the $\mu$ mol of $p$-Nitrophenyl released per milliliter of enzyme per minute. The $\mathrm{pH}$ was determined by a pH meter Delta320 (Mettler Toledo Instruments (Shanghai) Ltd., Shanghai, China). The pH was determined by a pH meter Delta320 (Mettler Toledo Instruments (Shanghai) Ltd., Shanghai, China). 


\section{RESULTS AND DISCUSSION}

\section{Carbon Source vs. BGL Production}

As shown in Fig. 1, the relatively highest BGL activity of $5.19 \pm 0.25 \mathrm{U} / \mathrm{mL}$ was obtained with corn cob as the carbon source, followed by straw powder, wheat bran, bagasse, rice bran, industrial cellulose, corn stalk, and starch. This result was similar to previous research (Relwani et al. 2008). However, the BGL activity in this paper was substantially lower than that of the authors' lab's previous study $(7.22 \mathrm{U} / \mathrm{mL})$ under similar conditions (Shi 2011), which might have been due to the degeneration of the mutant for undiscovered reasons.

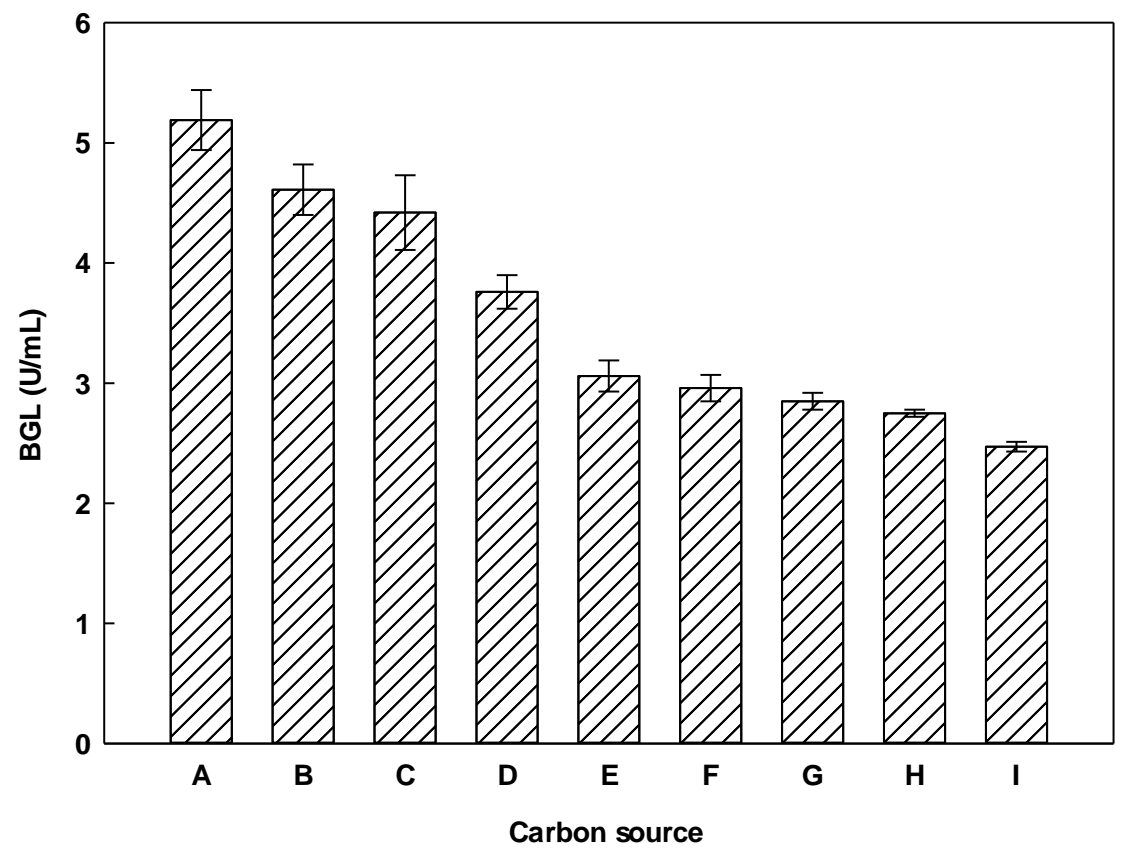

Fig. 1. Effect of single carbon source on BGL production; A through I represents corn cob, straw powder, wheat bran, bagasse, rice bran, industrial cellulose, corn stalk, and starch, respectively

Table 1. Particle Size of Carbon Source on BGL Production*

\begin{tabular}{|c|c|c|c|}
\hline BGL $(\mathrm{U} / \mathrm{mL})$ & $\begin{array}{c}\text { Corn Cob } \\
\text { (Untreated) }\end{array}$ & $\begin{array}{c}\text { Corn Cob } \\
(30 \text { Mesh) }\end{array}$ & $\begin{array}{c}\text { Corn Cob } \\
(50 \text { Mesh) }\end{array}$ \\
\hline $\begin{array}{c}\text { Straw Powder } \\
\text { (Untreated) }\end{array}$ & $5.19 \pm 0.24$ & $3.11 \pm 0.16$ & $7.48 \pm 0.21$ \\
\hline $\begin{array}{c}\text { Straw Powder } \\
(30 \text { Mesh) }\end{array}$ & $6.16 \pm 0.33$ & $4.29 \pm 0.27$ & $6.72 \pm 0.32$ \\
\hline $\begin{array}{c}\text { Straw Powder } \\
\text { (50 Mesh) }\end{array}$ & $5.49 \pm 0.25$ & $4.33 \pm 0.34$ & $6.06 \pm 0.46$ \\
\hline
\end{tabular}

${ }^{\star}$ The straw powder and corn cob were treated using a grinder and screened by different mesh sieves, orderly; the total dose of carbon source was $30 \mathrm{~g} / \mathrm{L}$; the ratio of straw to corn was 1.0

The substrate particle size, which affects the mass and heat transfer, attachment of microbes to substrate, accessibilities of nutrition, physio-chemical properties of fluent, etc., is usually studied in a solid-state fermentation (Thomas et al. 2013), rather than in a submerged fermentation (Izumi et al. 2010). As shown in Table 1, a smaller substrate particle size noticeably boosted BGL production, holding the relatively highest BGL 
activity of $7.48 \pm 0.21 \mathrm{U} / \mathrm{mL}$ (untreated straw powder +50 mesh corn cob), which might be due to the combined effect of more oligomers (e.g. cello-oligosaccharides) being released and moderate culture conditions (Thomas et al. 2013).

In Figs. 1 and 2, a carbon source cocktail was superior to a single source for BGL production. The activities of BGL decreased with increased ratios of corn cob/straw powder from 0.3 to 0.5 , and then increased from 1.0 to 2.0, with a maximum BGL activity of $8.81 \pm 0.19 \mathrm{U} / \mathrm{mL}$ (corn cob/straw powder ratio of 0.8 , corresponded to $13.3 \mathrm{~g} / \mathrm{L}$ corn cob and $16.7 \mathrm{~g} / \mathrm{L}$ straw powder), which was approximately double of that using corn cob as the carbon source. Commonly, agricultural residues (corn cob, straw powder, wheatstraw, etc.) are suitable substrates for BGL production. Moreover, a substrate cocktail has been proven to be better than a single substrate for BGL production, because more promoters and inducers (carbohydrates) are produced during the fermentation process (Delabona et al. 2013). Likewise, the diversity of substrates contributes to reduced costs in BGL production. Thus, for higher cost-effective BGL production, a carbon source cocktail (corn cob and straw powder with the ratio of 0.8) was selected for BGL production.

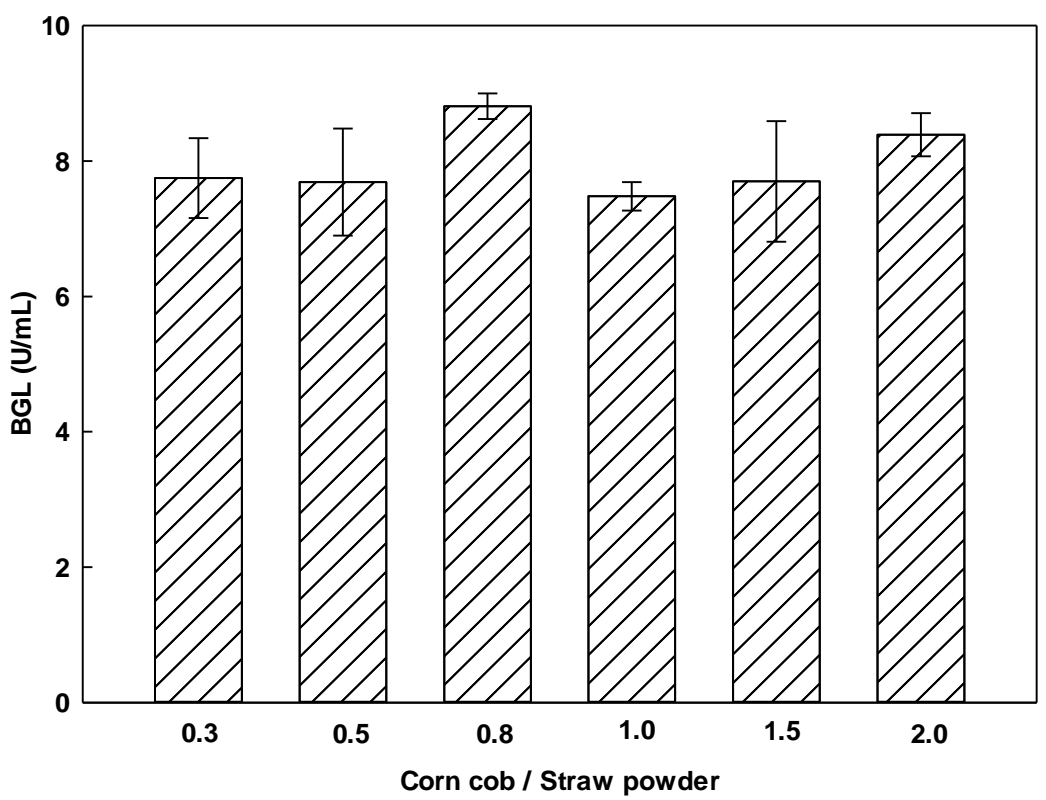

Fig. 2. Effect of single carbon source cocktail on BGL production

\section{Nitrogen Source vs. BGL Production}

In Fig. 3, the nitrogen source that influenced BGL secretion was ordered by $\left(\mathrm{NH}_{4}\right)_{2} \mathrm{SO}_{4}>\mathrm{NH}_{4} \mathrm{NO}_{3}>\mathrm{NH}_{4} \mathrm{NO}_{3}+\left(\mathrm{NH}_{4}\right)_{2} \mathrm{SO}_{4}>\left(\mathrm{NH}_{4}\right)_{2} \mathrm{SO}_{4}+$ Urea $>$ peptone $>$ peptone $+\left(\mathrm{NH}_{4}\right)_{2} \mathrm{SO}_{4}>$ urea, holding a relatively high BGL activity of $6.41 \pm 0.24 \mathrm{U} / \mathrm{mL}$. Generally, the inorganic nitrogen sources $\left(\left(\mathrm{NH}_{4}\right)_{2} \mathrm{SO}_{4}\right.$ and $\left.\mathrm{NH}_{4} \mathrm{NO}_{3}\right)$ performed somewhat superior to the organic ones (peptone and urea) for BGL production, which was not in accordance with some previous studies (Narasimha et al. 2006). It was reported that the effect of the nitrogen source on cellulase production was variable, relying on strains, nature, and the dose of nitrogen (Kachlishvili et al. 2006). Typically, inorganic nitrogen (e.g. ammonium) is more easily assimilated by fungal strains than organic nitrogen (e.g. urea). However, some of the amino acids in organic nitrogen sources (e.g. beef extract, yeast extract, and peptone) can be assimilated and directly incorporated into proteins, having the advantage of enzyme synthesis over inorganic sources (Gottschalk et al. 2013). 
Furthermore, the strategies of organic-inorganic (yeast extract $\left.+\left(\mathrm{NH}_{4}\right)_{2} \mathrm{SO}_{4}\right)$ (Wang et al. 2012) and inorganic-inorganic nitrogen $\left(\mathrm{NH}_{4} \mathrm{Cl}+\left(\mathrm{NH}_{4}\right)_{2} \mathrm{SO}_{4}\right)$ (Kumar and Singh 2001) complementation were successfully applied for BGL production. However in this paper, unsatisfactory results were obtained using both organic-inorganic $\left(\left(\mathrm{NH}_{4}\right)_{2} \mathrm{SO}_{4}+\right.$ Urea and peptone $\left.+\left(\mathrm{NH}_{4}\right)_{2} \mathrm{SO}_{4}\right)$ and inorganic-inorganic $\left(\mathrm{NH}_{4} \mathrm{NO}_{3}+\left(\mathrm{NH}_{4}\right)_{2} \mathrm{SO}_{4}\right)$ nitrogen compounds, which might be caused by the inhibitory effect on BGL production (Joo et al. 2010). Therefore, $\left(\mathrm{NH}_{4}\right)_{2} \mathrm{SO}_{4}$ was selected as the nitrogen source for BGL production.

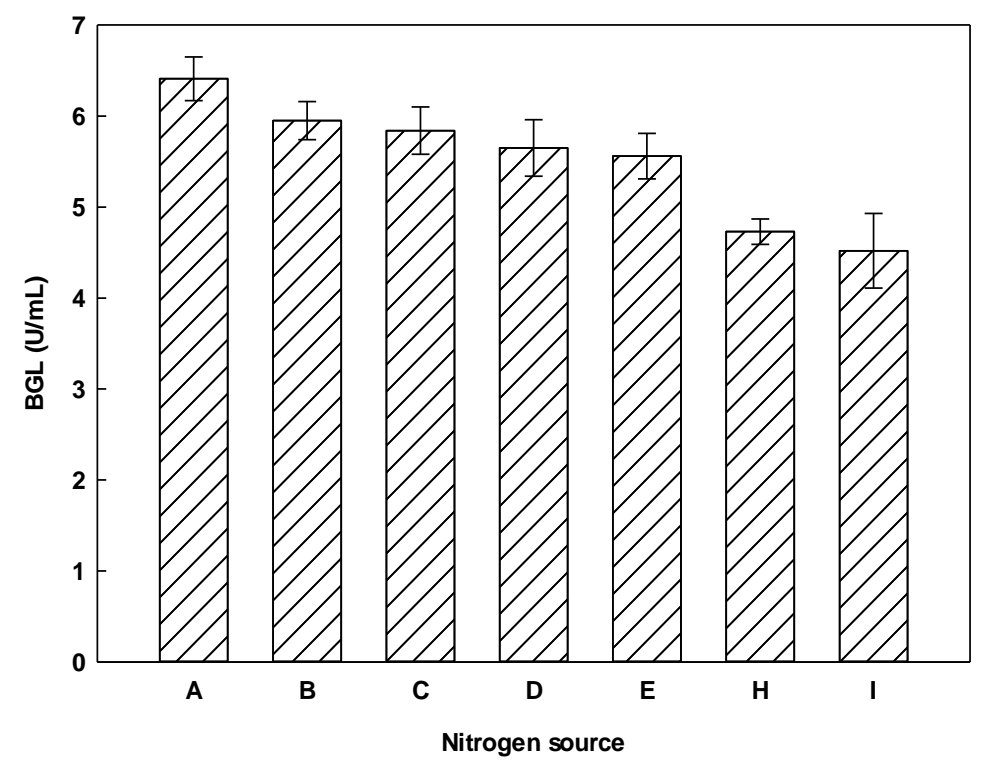

Fig. 3. Nitrogen source on BGL production, A through I represent nitrogen source: $\left.\mathrm{NH}_{4}\right)_{2} \mathrm{SO}_{4}$, $\mathrm{NH}_{4} \mathrm{NO}_{3}, \mathrm{NH}_{4} \mathrm{NO}_{3}+\left(\mathrm{NH}_{4}\right)_{2} \mathrm{SO}_{4},\left(\mathrm{NH}_{4}\right)_{2} \mathrm{SO}_{4}+$ urea, peptone, peptone $+\left(\mathrm{NH}_{4}\right)_{2} \mathrm{SO}_{4}$, and urea, respectively; all the complex nitrogen sources held the mass ratios of 1:1

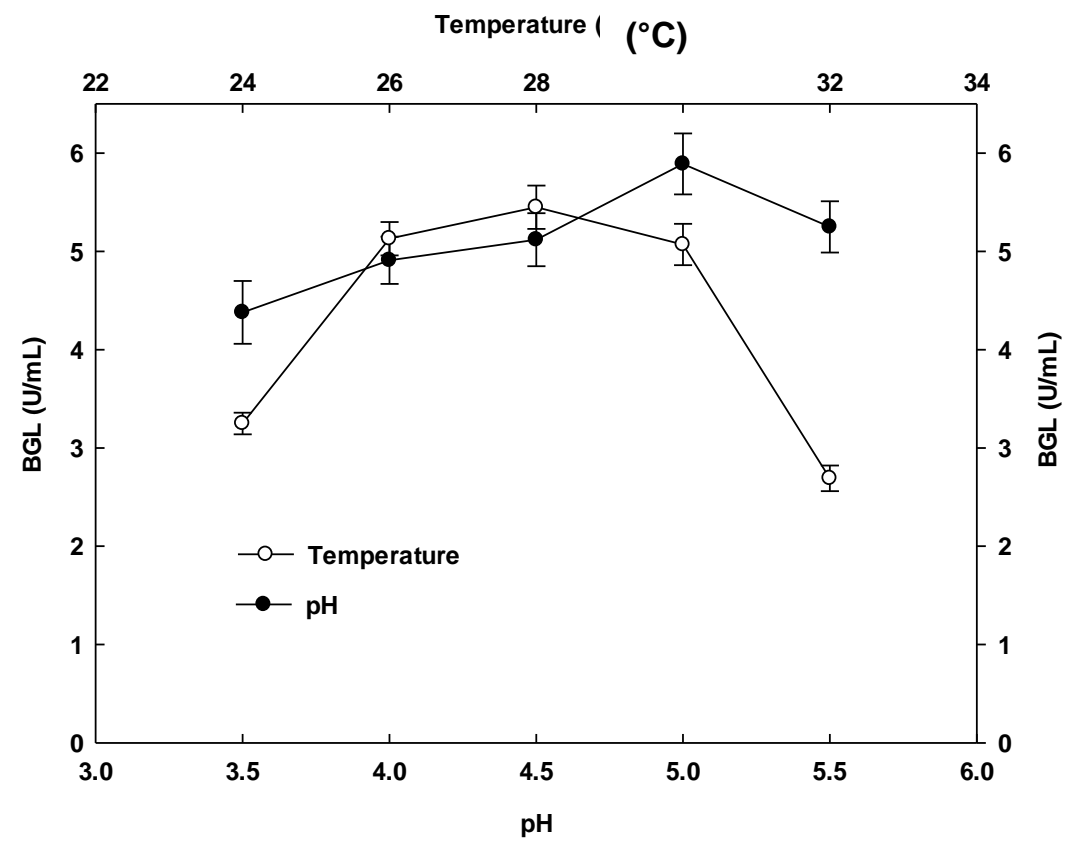

Fig. 4. Changes of temperature and $\mathrm{pH}$ in the $\mathrm{BGL}$ production process 


\section{Temperature and $\mathrm{pH}$ vs. BGL Production}

Generally, the culture $\mathrm{pH}$ and temperature greatly influence microbial growth, metabolic abilities (e.g. enzyme secreting), product properties (e.g. enzyme stability), etc. As shown in Fig. 4, the BGL activities increased during the initial temperature of $24.0^{\circ} \mathrm{C}$ to $28.0^{\circ} \mathrm{C}$ and then dropped notably, with a maximum BGL activity of $5.45 \mathrm{U} / \mathrm{mL} \pm 0.22$ $\mathrm{U} / \mathrm{mL}\left(28^{\circ} \mathrm{C}\right)$. Meanwhile, the BGL activities increased the initial $\mathrm{pH}$ from 3.5 to 5.0 and then dropped, holding a maximum BGL activity of $5.89 \pm 0.31 \mathrm{U} / \mathrm{mL}(\mathrm{pH} 5.0)$. The effects of $\mathrm{pH}$ and temperature on BGL production were similar to those of previous studies (Sohail et al. 2009).

Table 2. Results of Un-coded Process Variables and Observed, Predicted Responses

\begin{tabular}{|c|c|c|c|c|c|c|}
\hline \multirow{2}{*}{ Run } & \multicolumn{4}{|c|}{ Factors } & \multicolumn{2}{|c|}{$\begin{array}{l}\text { BGL } \\
(\mathrm{U} / \mathrm{mL})\end{array}$} \\
\hline & $\begin{array}{c}\text { A: Carbon } \\
(\mathrm{g} / \mathrm{L})\end{array}$ & $\begin{array}{c}\text { B: Nitrogen } \\
(\mathrm{g} / \mathrm{L})\end{array}$ & $\begin{array}{c}\text { C: Temperature } \\
\left({ }^{\circ} \mathrm{C}\right)\end{array}$ & $D: \mathrm{pH}$ & Observed & Predicted \\
\hline 1 & 30.0 & 7.5 & 28.0 & 5.0 & $8.80 \pm 0.28$ & 8.82 \\
\hline 2 & 30.0 & 7.5 & 28.0 & 5.0 & $8.83 \pm 0.30$ & 8.84 \\
\hline 3 & 40.0 & 7.5 & 28.0 & 4.5 & $8.08 \pm 0.19$ & 8.09 \\
\hline 4 & 30.0 & 10.0 & 25.0 & 5.0 & $7.31 \pm 0.20$ & 7.33 \\
\hline 5 & 30.0 & 10.0 & 28.0 & 4.5 & $7.38 \pm 0.24$ & 7.39 \\
\hline 6 & 20.0 & 7.5 & 25.0 & 5.0 & $6.94 \pm 0.17$ & 6.94 \\
\hline 7 & 30.0 & 7.5 & 30.0 & 4.5 & $7.22 \pm 0.31$ & 7.24 \\
\hline 8 & 30.0 & 5.0 & 25.0 & 5.0 & $7.24 \pm 0.25$ & 7.24 \\
\hline 9 & 20.0 & 5.0 & 28.0 & 5.0 & $6.99 \pm 0.28$ & 7.04 \\
\hline 10 & 40.0 & 7.5 & 25.0 & 5.0 & $7.97 \pm 0.31$ & 7.95 \\
\hline 11 & 40.0 & 7.5 & 30.0 & 5.0 & $8.14 \pm 0.23$ & 8.10 \\
\hline 12 & 20.0 & 7.5 & 30.0 & 5.0 & $6.93 \pm 0.30$ & 6.90 \\
\hline 13 & 40.0 & 7.5 & 28.0 & 5.5 & $8.12 \pm 0.35$ & 8.13 \\
\hline 14 & 30.0 & 5.0 & 28.0 & 4.5 & $7.36 \pm 0.31$ & 7.32 \\
\hline 15 & 30.0 & 7.5 & 25.0 & 4.5 & $7.17 \pm 0.28$ & 7.17 \\
\hline 16 & 40.0 & 10.0 & 28.0 & 5.0 & $8.24 \pm 0.29$ & 8.23 \\
\hline 17 & 20.0 & 7.5 & 28.0 & 5.5 & $7.06 \pm 0.17$ & 7.06 \\
\hline 18 & 30.0 & 7.5 & 25.0 & 5.5 & $7.26 \pm 0.24$ & 7.26 \\
\hline 19 & 30.0 & 7.5 & 28.0 & 5.0 & $8.84 \pm 0.33$ & 8.82 \\
\hline 20 & 40.0 & 5.0 & 28.0 & 5.0 & $8.08 \pm 0.31$ & 8.13 \\
\hline 21 & 30.0 & 10.0 & 30.0 & 5.0 & $7.39 \pm 0.28$ & 7.39 \\
\hline 22 & 30.0 & 5.0 & 30.0 & 5.0 & $7.30 \pm 0.33$ & 7.29 \\
\hline 23 & 30.0 & 5.0 & 28.0 & 5.5 & $7.43 \pm 0.26$ & 7.38 \\
\hline 24 & 30.0 & 7.5 & 30.0 & 5.5 & $7.26 \pm 0.19$ & 7.30 \\
\hline 25 & 20.0 & 7.5 & 28.0 & 4.5 & $6.96 \pm 0.28$ & 6.95 \\
\hline 26 & 30.0 & 10.0 & 28.0 & 5.5 & $7.48 \pm 0.34$ & 7.48 \\
\hline 27 & 20.0 & 10.0 & 28.0 & 5.0 & $7.13 \pm 0.36$ & 7.12 \\
\hline
\end{tabular}




\section{RSM Optimization}

The design and results of RSM are shown in Table 2 , wherein, a model $\left(\mathrm{R}^{2}=0.991\right)$ in terms of coded factors (carbon, nitrogen, temperature, and $\mathrm{pH}$ ) was simulated as follows,

$$
\begin{aligned}
& \mathrm{Y}=8.82+0.55 \mathrm{~A}+0.044 \mathrm{~B}-0.029 \mathrm{C}+0.037 \mathrm{D}+0.005 \mathrm{AB}-0.045 \mathrm{AC}-0.015 \mathrm{AD}- \\
& 0.005 \mathrm{BC}+0.0075 \mathrm{BD}+0.013 \mathrm{CD}-0.52 \mathrm{~A}^{2}-0.68 \mathrm{~B}^{2}-0.83 \mathrm{C}^{2}-0.75 \mathrm{D}^{2}
\end{aligned}
$$

where $Y$ is BGL $(\mathrm{U} / \mathrm{mL}), A$ is carbon $(\mathrm{mg} / \mathrm{L}), B$ is nitrogen $(\mathrm{mg} / \mathrm{L}), C$ is temperature $\left({ }^{\circ} \mathrm{C}\right)$, and $D$ is $\mathrm{pH}$.

The four factors influenced BGL production significantly $(\mathrm{P}<0.0001)$ (Table 3). While the interaction of carbon and temperature influenced BGL production significantly $(\mathrm{P}<0.05)$, the others did not $(\mathrm{P}>0.05)$. Moreover, a maximum BGL $(8.97 \mathrm{U} / \mathrm{mL})$ was obtained by optimizing the RSM model, holding the corresponding carbon, nitrogen, temperature, and $\mathrm{pH}$ of $35.35 \mathrm{~g} / \mathrm{L}, 7.59 \mathrm{~g} / \mathrm{L}, 27.94{ }^{\circ} \mathrm{C}$, and 5.03 , respectively. Three replicated experiments were performed to verify the validity of the optimized conditions, holding a maximum BGL $(8.91 \pm 0.35 \mathrm{U} / \mathrm{mL})$. The model was effective and accurate for predicting the production of BGL.

Table 3. Analysis of Variance (ANOVA) for Observed Factors

\begin{tabular}{|c|c|c|c|c|c|}
\hline Sources & Square Sum & Freedom & Mean Square & F value & P value \\
\hline Model & 9.28 & 14 & 0.66 & 531.65 & $<0.0001$ \\
\hline$A$ & 3.65 & 1 & 3.65 & 2929.76 & $<0.0001$ \\
\hline$B$ & 0.023 & 1 & 0.023 & 18.780 & 0.001 \\
\hline$C$ & 0.01 & 1 & 0.01 & 8.19 & 0.0143 \\
\hline$D$ & 0.016 & 1 & 0.016 & 12.940 & 0.0037 \\
\hline$A B$ & $1.00 \mathrm{E}-04$ & 1 & $1.00 \mathrm{E}-04$ & 0.08 & 0.7818 \\
\hline$A C$ & $8.10 \mathrm{E}-03$ & 1 & $8.10 \mathrm{E}-03$ & 6.50 & 0.0255 \\
\hline$A D$ & $9.00 \mathrm{E}-04$ & 1 & $9.00 \mathrm{E}-04$ & 0.72 & 0.4121 \\
\hline$B C$ & $1.00 \mathrm{E}-04$ & 1 & $1.00 \mathrm{E}-04$ & 0.08 & 0.7818 \\
\hline$B D$ & $2.25 \mathrm{E}-04$ & 1 & $2.25 \mathrm{E}-04$ & 0.18 & 0.6785 \\
\hline$C D$ & $6.25 \mathrm{E}-04$ & 1 & $6.25 \mathrm{E}-04$ & 0.50 & 0.4924 \\
\hline$A^{2}$ & 1.42 & 1 & 1.42 & 1142.14 & $<0.0001$ \\
\hline$B^{2}$ & 2.47 & 1 & 2.47 & 1980.83 & $<0.0001$ \\
\hline$C^{2}$ & 3.68 & 1 & 3.68 & 2950.45 & $<0.0001$ \\
\hline$D^{2}$ & 2.99 & 1 & 2.99 & 2401.34 & $<0.0001$ \\
\hline $\begin{array}{c}\text { Residual } \\
\text { Error }\end{array}$ & 0.015 & 12 & $1.25 \mathrm{E}-03$ & & \\
\hline $\begin{array}{c}\text { Lack of Fit } \\
\text { Value }\end{array}$ & 0.014 & 10 & $1.41 \mathrm{E}-03$ & 3.250 & 0.258 \\
\hline Pure Error & $8.67 \mathrm{E}-04$ & 2 & $4.33 \mathrm{E}-04$ & & \\
\hline Sum & 9.29 & 26 & & & \\
\hline
\end{tabular}

\section{Process Dynamic Characteristics}

As an indicator of particle electrical charge properties (e.g. positively or negatively charged) of amphoteric matters (e.g. protein, enzyme and cell membrane), zeta potential has usually been measured in submerged fermentation (Jeon et al. 2013; Singh et al. 2014). Generally, the zeta potential presents negative or positive value when the amphoteric matter isoelectric point ( $\mathrm{pI}$ ) is less or more than the solution $\mathrm{pH}$, respectively (Bowen et al. 1998). 


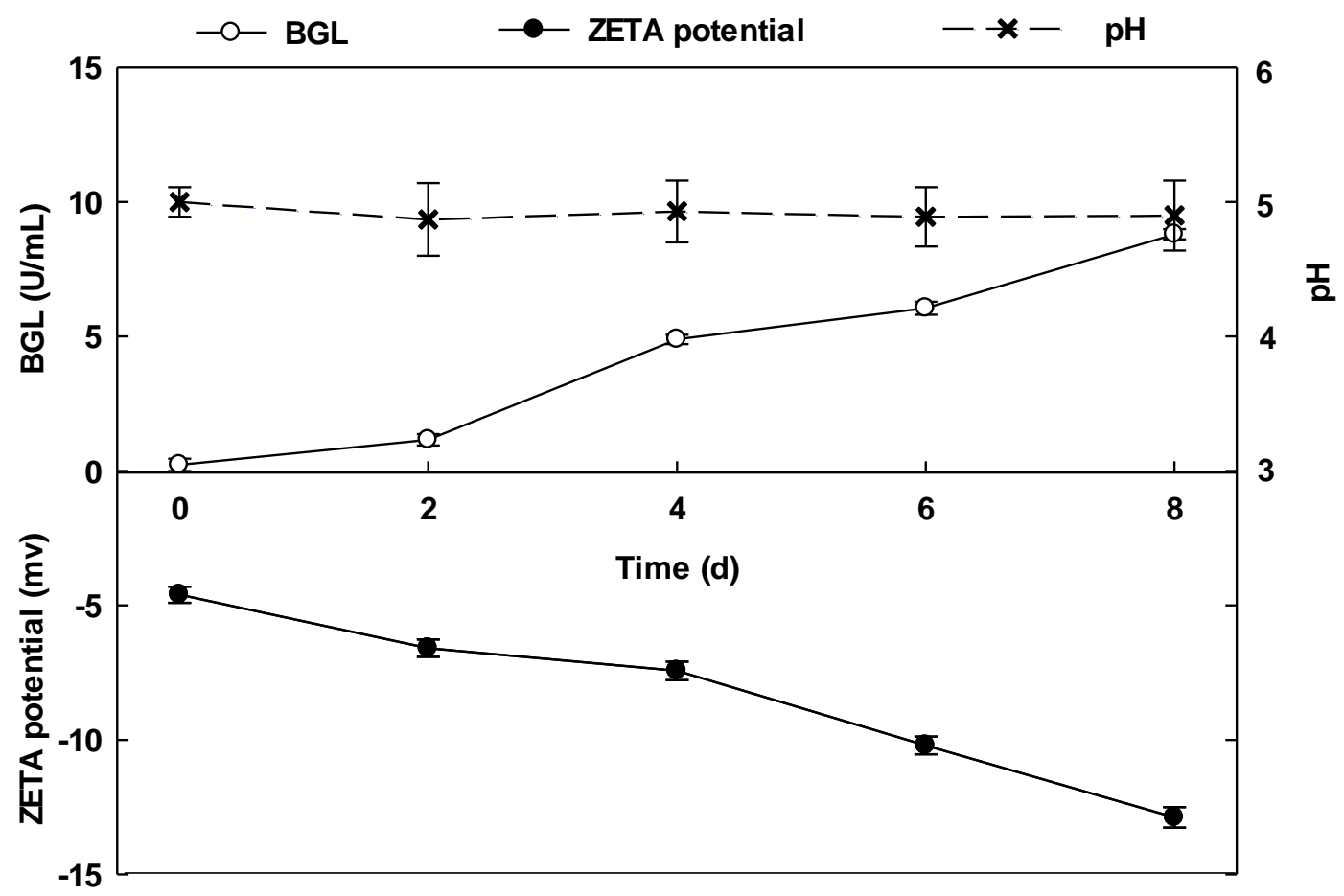

Fig. 5. Dynamic of zeta potential, BGL, and $\mathrm{pH}$ over time

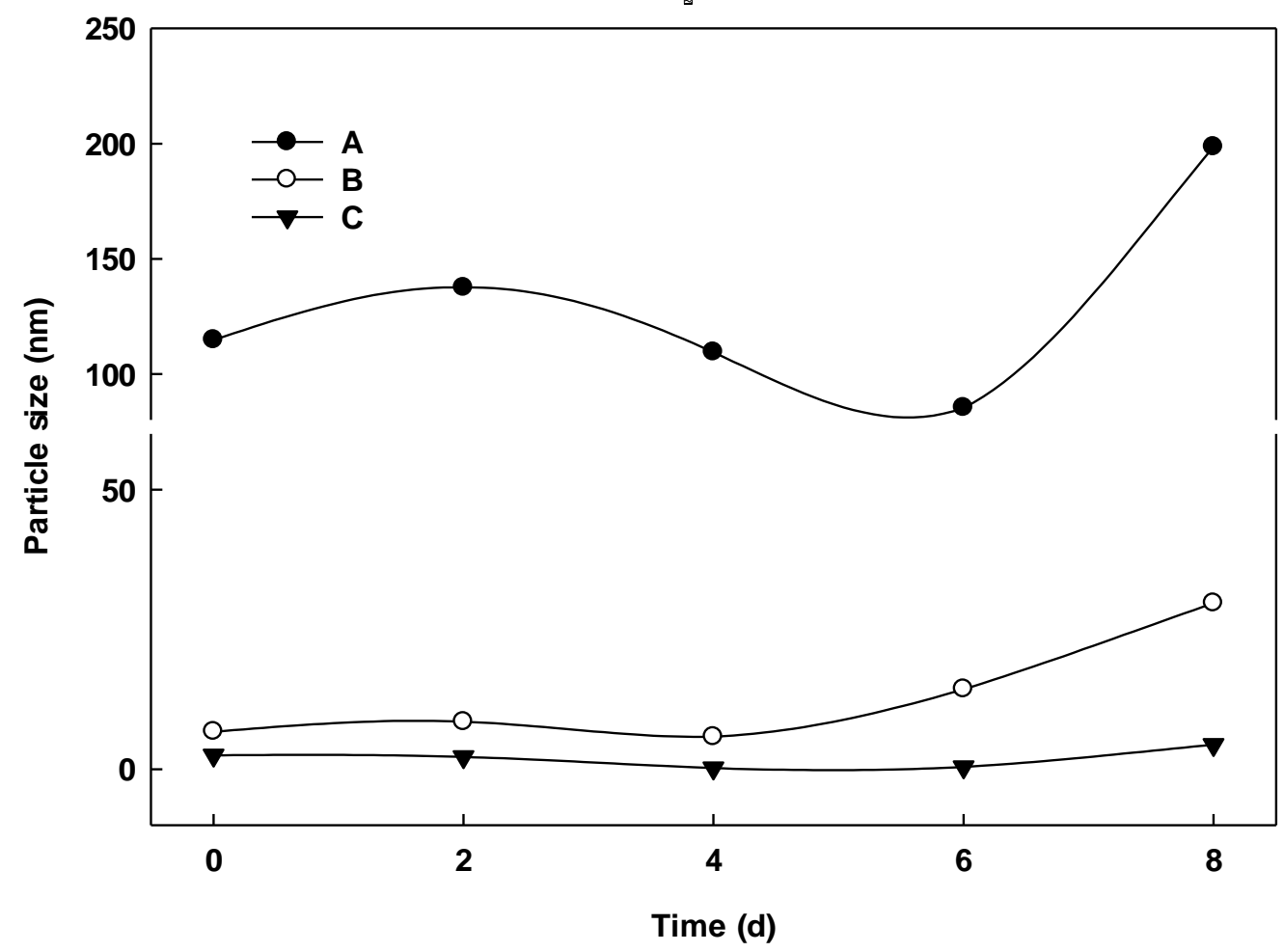

Fig. 6. Dynamic of DOMs particle size over time; A, B, C represent the highest amount of unknown particles exited in three ranges: $80 \mathrm{~nm}$ to $200 \mathrm{~nm}, 5 \mathrm{~nm}$ to $80 \mathrm{~nm}$, and $<5 \mathrm{~nm}$, respectively 
It was reported that the $\mathrm{pI}$ of BGL secreted by A. niger strains was from 3.20 to 4.05 (McCleary and Harrington 1988; Shoseyov et al. 1988; Watanabe et al. 1992; Unno et al. 1993; Yan and Lin 1997; Lambert et al. 2003), which was less than the $\mathrm{pH}$ of the broth used in this work (which fluctuated around 4.5) (Fig. 5), leading to the BGL surface being negatively charged.

Besides, it is known that the microbial cellulases (e.g. BGL) are expressed only under the conditions in which induced cello-oligosaccharides (e.g. sophorose) were present, which are mainly enzymatic hydrolyzed from the lignocellulose carbon sources. Accompanied by the releasing of cello-oligosaccharides, plenty of carboxyl groups are exposed and attached to the cellulosic surfaces, causing the lignocellulose carbon sources negatively charged (Peri et al. 2012). It was described from Fig. 5, possibly due to the combined effects of negatively charged BGL and cellulosic particle, the zeta potential of broth increased with the yield of BGL over the whole fermentation process $(-4.6 \mathrm{mV}$ to $12.88 \mathrm{mV}$ ). The DOMs particle sizes ( $8 \mathrm{~nm}$ to $200 \mathrm{~nm}$ and $5 \mathrm{~nm}$ to $80 \mathrm{~nm}$ ) increased over time despite some drops at some time for unknown reasons (Fig. 6). The dynamics of zeta potential and DOMs particle size might be related to the production of enzymes and degradation of carbon substrates, and ultimately lead to effects on process operations like product separation and extraction.

The EEM method has recently been widely used for characterizing DOMs in liquid media (wastewater, activated sludge, fermentation broth, etc.), primarily for the advantage of cheap and rapid determination of DOMs according to their unique fluorescence spectra information (Wan et al. 2012). In addition, it was reported that there are commonly five components of DOMs - aromatic protein, aromatic protein II, fulvic acid-like, soluble microbial byproduct-like, and humic acid-like - with definitive Ex/Em values, (220 to $250) /(280$ to 330$) \mathrm{nm},(220$ to 250$) /(330$ to 380$) \mathrm{nm},(220$ to 250$) /(380$ to 500$) \mathrm{nm},(250$ to $400) /(280$ to 380$) \mathrm{nm}$, and (250 to 400$) /(380$ to 500$) \mathrm{nm}$, respectively (Chen et al. 2003). For a deeper understanding of the dynamics of DOMs in fermentation broth, the EEM method was applied in this work. In Fig. 7, four components of DOMs (aromatic protein II, fulvic acid-like, soluble microbial byproduct-like, and humic acid-like matters) were determined in the samples. The humic acid-like matters were the main components, mostly accounting for half of the total fluorescence relative intensities (Fig. 10), with the peak Ex/Em values of 390/485 nm (0 d), 380/458 nm (2 d), 390/467 nm (4 d), 400/494 nm (6 d), and 400/494 $\mathrm{nm}(8 \mathrm{~d})$, respectively. Moreover, the $f_{450 / 500}$ values of the samples decreased from the initial $1.36(0 \mathrm{~d})$ to $0.85(8 \mathrm{~d})$, indicating that humic acid-like matter were mainly derived from the carbon source cocktail (Mcknight et al. 2001) and were consequently influenced by $A$. niger $\mathrm{C} 112$ to some extent. In addition, the increases of aromatic protein II and soluble microbial byproduct-like matters over time (not during the period of $0 \mathrm{~d}$ to $2 \mathrm{~d}$ ) were probably due in part to enzyme secretion of $A$. niger $\mathrm{C} 112$ (Fig. 8), leaving room for further research to be conducted. Furthermore, the ratios of fluorescence intensities of fulvic acid-like matters to humic acid-like matter were small ( 0.28 to 0.46 , calculated by the values in Fig. 7 ), meaning high degrees of humification of the substrates (Wei et al. 2014). 

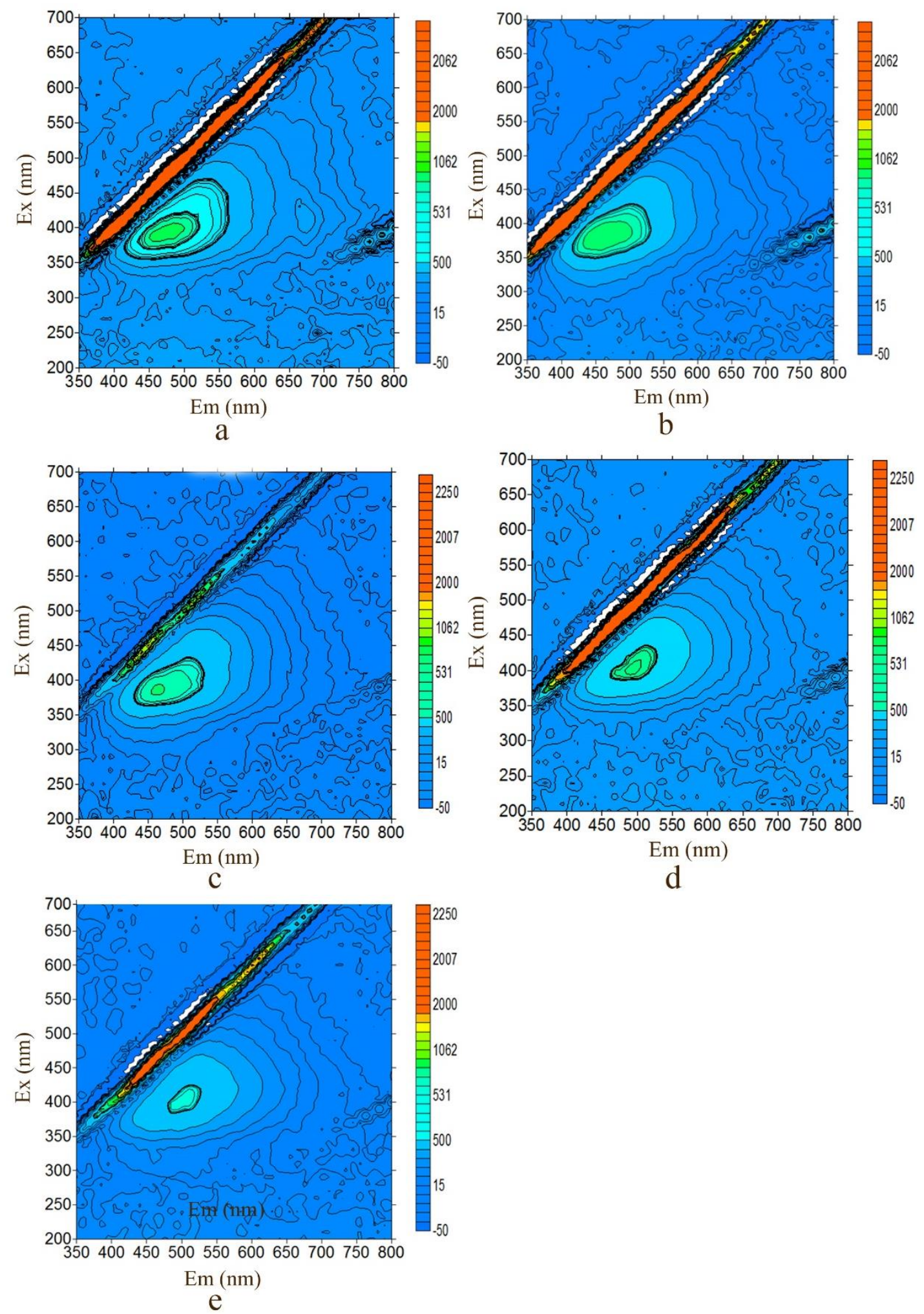

Fig. 7. EEM fluorescence spectra of samples; a, b, c, d, and e represent the sample: $0 \mathrm{~d}, 2 \mathrm{~d}, 4 \mathrm{~d}$, $6 \mathrm{~d}$, and $8 \mathrm{~d}$, respectively 


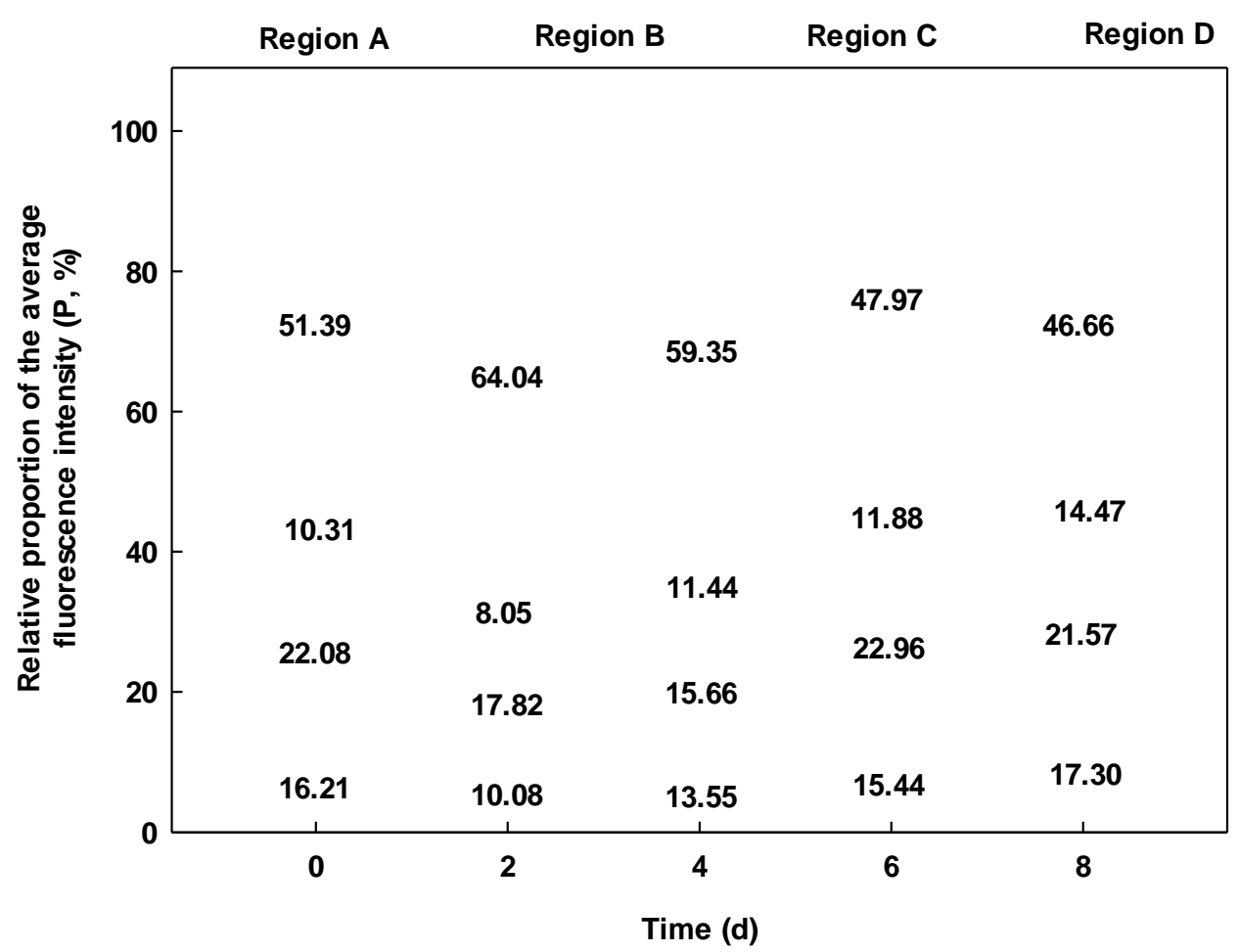

Fig. 8. EEM fluorescence spectra of samples; region A through D represent aromatic protein II, fulvic acid-like, soluble microbial by-product-like, and humic acid-like, respectively

\section{CONCLUSIONS}

1. The mutant strain $A$. niger $\mathrm{C} 112$ was successfully used for cost-effective $\beta$-glucosidase (BGL) production. A maximum BGL activity of $8.91 \pm 0.35 \mathrm{U} / \mathrm{mL}$ was obtained by medium and process optimization, with the carbon cocktail (straw powder + corn cob), nitrogen $\left(\left(\mathrm{NH}_{4}\right)_{2} \mathrm{SO}_{4}\right)$, temperature, and $\mathrm{pH}$ of $35.35 \mathrm{~g} / \mathrm{L}, 7.59 \mathrm{~g} / \mathrm{L}, 27.94{ }^{\circ} \mathrm{C}$, and 5.03 , respectively.

2. Possibly due to the combined effect of more oligomers released and moderate culture conditions, the carbon source cocktail performed significantly superior to the single substrate.

3. This is the first report on the application of the excitation-emission matrix (EEM) fluorescence spectroscopy method for understanding and characterizing the components, origin, and dynamics of dissolved organic matter (DOMs) involved in BGL production, contributing to further process optimization.

\section{ACKNOWLEDGMENTS}

This work was supported by the National Special Program for International Science and Technology Cooperation (No. 2015DFA01120), the National Special Research Program for Public Causes (No. 201404604), the Natural Science Foundation of Hunan Province (Nos. 2017JJ2412, 2015JJ5007), the Key Research and Development 
Program of Hunan Province (No. 2016NK2149), and the National Natural Science Foundation of China (No. 21407046). The authors are also thankful for the help of Dr. Jianwei Zhao of Hunan University for F-4600 FL spectrophotometer operation.

\section{REFERENCES CITED}

Abdella, A., El-Sayed Mazeed, T., Yang, S. T., and El-Baz, A. F. (2014). "Production of $\beta$ glucosidase by Aspergillus niger on wheat bran and glycerol in submerged culture: Factorial experimental design and process optimization," Current Biotechnology 3(2), 197-206. DOI: 10.2174/2211550103666140508203241

Barati, B., and Sadegh Amiri, I. (2015). "Literature review of cellulase and approaches to increase its stability," in: In Silico Engineering of Disulphide Bonds to Produce Stable Cellulase, B. Barati and I. Sadegh Amiri (Eds.), Springer Singapore, Singapore.

Bowen, W. R., Hall, N. J., Pan, L. C., Sharif, A. O., and Williams, P. M. (1998). "The relevance of particle size and zeta-potential in protein processing," Nature Biotechnology 16(8), 785. DOI: 10.1038/nbt0898-785

Chen, W., Westerhoff, P., Leenheer, J. A., and Booksh, K. (2003). "Fluorescence excitation-emission matrix regional integration to quantify spectra for dissolved organic matter," Environmental Science \& Technology 37(24), 5701-5710. DOI: 10.1021/es034354c

Delabona, P. d. S., Pirota, R. D. P. B., Codima, C. A., Tremacoldi, C. R., Rodrigues, A., and Farinas, C. S. (2013). "Effect of initial moisture content on two Amazon rainforest Aspergillus strains cultivated on agro-industrial residues: Biomassdegrading enzymes production and characterization," Industrial Crops and Products 42(3), 236-242. DOI: 10.1016/j.indcrop.2012.05.035

Elanthikkal, S., Gopalakrishnapanicker, U., Varghese, S., and Guthrie, J. T. (2010). "Cellulose microfibres produced from banana plant wastes: Isolation and characterization," Carbohydrate Polymers 80(3), 852-859. DOI:

10.1016/j.carbpol.2009.12.043

Escamilla-Alvarado, C., Pérez-Pimienta, J. A., Ponce-Noyola, T., and Poggi-Varaldo, H. M. (2016). "An overview of the enzyme potential in bioenergy-producing biorefineries," Journal of Chemical Technology \& Biotechnology 92(5), 906-924. DOI: $10.1002 /$ jetb.5088

Fujita, Y., Ito, J., Ueda, M., Fukuda, H., and Kondo, A. (2004). "Synergistic saccharification, and direct fermentation to ethanol, of amorphous cellulose by use of an engineered yeast strain codisplaying three types of cellulolytic enzyme," Applied and Environmental Microbiology 70(2), 1207-1212. DOI: 10.1128/AEM.70.2.12071212.2004

Gottschalk, L. M. F., Paredes, R. D. S., Teixeira, R. S. S., Silva, A. S. A. D., and Bon, E. P. D. S. (2013). "Efficient production of lignocellulolytic enzymes xylanase, $\beta$ xylosidase, ferulic acid esterase and $\beta$-glucosidase by the mutant strain Aspergillus awamori 2B.361 U2/1," Brazilian Journal of Microbiology 44(2), 569-76. DOI: 10.1590/S1517-83822013000200037

Hasunuma, T., Okazaki, F., Okai, N., Hara, K. Y., Ishii, J., and Kondo, A. (2013). "A review of enzymes and microbes for lignocellulosic biorefinery and the possibility of their application to consolidated bioprocessing technology," Bioresource Technology 135, 513-522. DOI: 10.1016/j.biortech.2012.10.047 
He, X. S., Xi, B. D., Cui, D. Y., Liu, Y., Tan, W. B., Pan, H. W., and Li, D. (2014). "Influence of chemical and structural evolution of dissolved organic matter on electron transfer capacity during composting," Journal of Hazardous Materials 268(3), 256-263. DOI: 10.1016/j.jhazmat.2014.01.030

Izumi, K., Okishio, Y. K., Nagao, N., Niwa, C., Yamamoto, S., and Toda, T. (2010). "Effects of particle size on anaerobic digestion of food waste," International Biodeterioration \& Biodegradation 64(7), 601-608. DOI: 10.1016/j.ibiod.2010.06.013

Jeoh, T., Cardona, M. J., Karuna, N., Mudinoor, A. R., and Nill, J. (2017). "Mechanistic kinetic models of enzymatic cellulose hydrolysis-A review," Biotechnology \& Bioengineering 114(7), 1369-1385. DOI: 10.1002/bit.26277

Jeon, B. H., Choi, J. A., Kim, H. C., Hwang, J. H., Abou-Shanab, R. A., Dempsey, B. A., Regan, J. M., and Kim, J. R. (2013). "Ultrasonic disintegration of microalgal biomass and consequent improvement of bioaccessibility/bioavailability in microbial fermentation," Biotechnology for Biofuels 6(1), 37. DOI: 10.1186/1754-6834-6-37

Joo, A. R., Jeya, M., Lee, K. M., Lee, K. M., Moon, H. J., Kim, Y. S., and Lee, J. K. (2010). "Production and characterization of $\beta$-1,4-glucosidase from a strain of Penicillium pinophilum," Process Biochemistry 45(6), 851-858. DOI: 10.1016/j.procbio.2010.02.005

Lambert, W. D., Du, L., Ma, Y., Loha, V., Burapatana, V., Prokop, A., Tanner, R. D., and Pamment, N. B. (2003). "The effect of $\mathrm{pH}$ on the foam fractionation of $\beta$-glucosidase and cellulase," Bioresource Technology 87(3), 247-253. DOI: 10.1016/S09608524(02)00240-7

Lotfy, W. A., Ghanem, K. M., and El-Helow, E. R. (2007). "Citric acid production by a novel Aspergillus niger isolate: I. Mutagenesis and cost reduction studies," Bioresource Technology 98(18), 3464-3469. DOI: 10.1016/j.biortech.2006.11.007

Kachlishvili, E., Penninckx, M. J., Tsiklauri, N., and Elisashvili, V. (2006). "Effect of nitrogen source on lignocellulolytic enzyme production by white-rot basidiomycetes under solid-state cultivation," World Journal of Microbiology and Biotechnology 22(4), 391-397. DOI: 10.1007/s11274-005-9046-8

Khattab, A. A., and Bazaraa, W. A. (2005). "Screening, mutagenesis and protoplast fusion of Aspergillus niger for the enhancement of extracellular glucose oxidase production," Journal of Industrial Microbiology and Biotechnology 32(7), 289-294. DOI: 10.1007/s10295-005-0249-7

Kumar, R., and Singh, R. P. (2001). "Semi-solid-state fermentation of Eicchornia crassipes biomass as lignocellulosic biopolymer for cellulase and $\beta$-glucosidase production by cocultivation of Aspergillus niger RK3 and Trichoderma reesei MTCC164," Applied Biochemistry and Biotechnology 96(1), 71-82. DOI: 10.1385/ABAB:96:1-3:071

Li, W., Chen, G., Gu, L., Zeng, W., and Liang, Z. (2014). "Genome shuffling of Aspergillus niger for improving transglycosylation activity," Applied Biochemistry and Biotechnology 172(1), 50-61. DOI: 10.1007/s12010-013-0421-x

Lu, X., Sun, J., Nimtz, M., Wissing, J., Zeng, A. P., and Rinas, U. (2010). "The intra- and extracellular proteome of Aspergillus niger growing on defined medium with xylose or maltose as carbon substrate," Microbial Cell Factories 9(1), 1-13. DOI:

$10.1186 / 1475-2859-9-23$ 
Mahalakshmi, C., Samson, S. M., Alagendran, S., Anusha, R., and Neelamathi, E. (2009). "Effect of UV and EMS mutation on Aspergillus niger in the production of alphaamylase," Journal of Pure and Applied Microbiology 3(2), 705-708.

Maity, S. K. (2015). "Opportunities, recent trends and challenges of integrated biorefinery: Part I," Renewable \& Sustainable Energy Reviews 43(1), 1427-1445. DOI: 10.1016/j.rser.2014.11.092

McCleary, B. V., and Harrington, J. (1988). "Purification of $\beta$-D-Glucosidase from Aspergillus niger," Methods in Enzymology 160, 575. DOI: 10.1016/0076-6879(88) 60171-6

McKnight, D. M., Boyer, E. W., Westerhoff, P. K., Doran, P. T., Kulbe, T., and Andersen, D. T. (2001). "Spectrofluorometric characterization of dissolved organic matter for indication of recursor organic material and aromaticity," Limnology \& Oceanography 46(1), 38-48. DOI: 10.4319/1o.2001.46.1.0038

Narasimha, G., Sridevi, A., Viswanath, B., Subhosh Chandra, M., and Rajasekhar Reddy, B. (2006). "Nutrient effects on production of cellulolytic enzymes by Aspergillus niger," African Journal of Biotechnology 5(5), 472-476.

Narasimha, G., Sridevi, A., Ramanjaneyulu, G., and Rajasekhar Reddy, B. (2016). "Purification and characterization of $\beta$-Glucosidase from Aspergillus niger," International Journal of Food Properties 19(3), 652-661. DOI:

10.1080/10942912.2015.1023398

Ottenheim, C., Werner, K. A., Zimmermann, W., and Wu, J. C. (2015). "Improved endoxylanase production and colony morphology of Aspergillus niger DSM 26641 by $\gamma$-ray induced mutagenesis," Biochemical Engineering Journal 94(15), 9-14. DOI: 10.1016/j.bej.2014.10.020

Pal, S. K., and Das, T. K. (2005). "Biochemical characterization of N-methyl N'-nitro-Nnitrosoguanidine-induced cadmium resistant mutants of Aspergillus niger," Journal of Biosciences 30(5), 639-646. DOI: 10.1007/BF02703564

Park, Y., Kang, S., Lee, J., Hong, S., and Kim, S. (2002). "Xylanase production in solid state fermentation by Aspergillus niger mutant using statistical experimental designs," Applied Microbiology and Biotechnology 58(6), 761-766. DOI: 10.1007/s00253-0020965-0

Peri, S., Muthukumar, L., Karim, M. N., and Khare, R. (2012). "Dynamics of cellooligosaccharides on a cellulose crystal surface," Cellulose 19(6), 1791-1806. DOI:10.1007/s10570-012-9771-8

Rani, V., Mohanram, S., Tiwari, R., Nain, L., and Arora, A. (2014). "Beta-glucosidase: Key enzyme in determining efficiency of cellulase and biomass hydrolysis," Journal of Bioprocessing \& Biotechniques 5, 197. DOI: 10.4172/2155-9821.1000197

Relwani, L., Krishna, P., and Sudhakara Reddy, M. (2008). "Effect of carbon and nitrogen sources on phosphate solubilization by a wild-type strain and UV-induced mutants of Aspergillus tubingensis," Current Microbiology 57(5), 401-406. DOI: 10.1007/s00284-008-9212-y

Shi, C. (2011). $\beta$-glucosidase Study from Mutation and Selection of Aspergillus niger, Master's Thesis, Central South University of Forestry and Technology, Changsha, China.

Shoseyov, O., Bravdo, B. A., Ikan, R., and Chet, I. (1988). "Endo- $\beta$-glucosidase from Aspergillus niger grown on a monoterpene glycoside-containing medium," Phytochemistry 27(7), 1973-1976. DOI: 10.1016/0031-9422(88)80080-3 
Singh, R., Shukla, A., Tiwari, S., and Srivastava, M. (2014). "A review on delignification of lignocellulosic biomass for enhancement of ethanol production potential," Renewable \& Sustainable Energy Reviews 32(5), 713-728. DOI: 10.1016/j.rser.2014.01.051

Sohail, M., Siddiqi, R., Ahmad, A., and Khan, S. A. (2009). "Cellulase production from Aspergillus niger MS82: Effect of temperature and pH," New Biotechnology 25(6), 437-441. DOI: 10.1016/j.nbt.2009.02.002

Stricker, A. R., Mach, R. L., and de Graaff, L. H. (2008). "Regulation of transcription of cellulases- and hemicellulases-encoding genes in Aspergillus niger and Hypocrea jecorina (Trichoderma reesei)," Applied Microbiology and Biotechnology 78(2), 211220. DOI: $10.1007 / \mathrm{s} 00253-007-1322-0$

Thomas, L., Larroche, C., and Pandey, A. (2013). "Current development in solid-state fermentation," Biochemical Engineering Journal 81(4), 146-161. DOI: 10.1016/j.bej.2013.10.013

Unno, T., Ide, K., Yazaki, T., Tanaka, Y., Nakakuki, T., and Okada, G. (1993). "High recovery purification and some properties of a $\beta$-glucosidase from Aspergillus niger," Bioscience Biotechnology and Biochemistry 57(12), 2172-2173. DOI: $10.1271 / \mathrm{bbb} .57 .2172$

Wan, S., Xi, B., Xia, X., Li, M., Lv, D., Lei, W., and Song, C. (2012). "Using fluorescence excitation-emission matrix spectroscopy to monitor the conversion of organic matter during anaerobic co-digestion of cattle dung and duck manure," Bioresource Technology 123(2), 439-444. DOI: 10.1016/j.biortech.2012.04.001

Wang, C., Wu, G., Chen, C., and Chen, S. (2012). "High production of $\beta$-glucosidase by Aspergillus niger on corncob," Applied Biochemistry and Biotechnology 168(1) 5867. DOI: 10.1007/s12010-011-9323-y

Wang, S., Lin, C., Liu, Y., Shen, Z., Jeyaseelan, J., and Qin, W. (2016). "Characterization of a starch-hydrolyzing $\alpha$-amylase produced by Aspergillus niger WLB42 mutated by ethyl methanesulfonate treatment," International Journal of Biochemistry and Molecular Biology 7(1), 1-10.

Watanabe, T., Sato, T., Yoshioka, S., Koshijima, T., and Kuwahara, M. (1992). "Purification and properties of Aspergillus niger $\beta$-glucosidase," European Journal of Biochemistry 209(2), 651-659. DOI: 10.1111/j.1432-1033.1992.tb17332.x

Wei, Z., Zhao, X., Zhu, C., Xi, B., Zhao, Y., and Yu, X. (2014). "Assessment of humification degree of dissolved organic matter from different composts using fluorescence spectroscopy technology," Chemosphere 95(1), 261. DOI: 10.1016/j.chemosphere.2013.08.087

Yan, T. R., and Lin, C. L. (1997). "Purification and characterization of a glucose-tolerant $\beta$-Glucosidase from Aspergillus niger CCRC 31494," Bioscience Biotechnology and Biochemistry 61(6), 965-970. DOI: 10.1271/bbb.61.965

Article submitted: June 20, 2017; Peer review completed: September 9, 2017; Revised version received and accepted: September 26, 2017; Published: October 11, 2017.

DOI: 10.15376/biores.12.4.8937-8952 